\title{
CORPORATE CRIMINAL LIABILITY IN SOUTH AFRICA: WHAT DOES HISTORY TELL US ABOUT THE REVERSE ONUS PROVISION?
}

\section{Dorothy Mmakgwale Farisani*}

\section{ABSTRACT}

An inevitable outcome of the coming into being of the Constitution in South Africa was the existence of a number of statutes or provisions within statutes that infringed some of the constitutionally entrenched rights. This led to the Constitutional Court finding itself faced with the responsibility of determining whether such provisions

* Associate Professor, Department of Mercantile Law, University of South Africa. Some parts of this article are adapted from sections of the author's unpublished $\mathrm{PhD}$ thesis (A Comparative Study of Corporate Criminal Liability - Advancing an Argument for the Reform of Corporate Criminal Liability in South Africa by Introducing a New Offence of Corporate Homicide, University of KwaZulu-Natal, 2016). The article forms part of research undertaken by the author during a period of research and development leave granted by the University of South Africa. Any opinions or conclusions expressed in the article are those of the author and therefore the University of South Africa does not accept any liability for them. 
were in line with the Constitution or not. Many matters of this nature were heard during the period immediately after the promulgation of the Constitution. In South Africa corporate criminal liability is regulated by section 332 of the Criminal Procedure Act 1977 . With regard to corporate criminal liability, the Constitutional Court heard a matter in which a reverse onus provision contained in section 332(5) of the Criminal Procedure Act was successfully challenged and declared invalid as it infringed the accused person's right to presumed innocent until proven guilty. Twenty years later, section 332 of the Criminal Procedure Act continues to exist with a sub-section that contains wording that is analogous to the invalidated section $332(5)$. In section 332(7) the reverse onus provision exists, albeit against members of associations that do not have legal personality. The sub-section has not been constitutionally challenged. However, the Constitutional Court, shortly after the coming into existence of the Constitution, heard several cases in which the validity of reverse onus provisions that infringed upon the right to be presumed innocent were successfully challenged. This article will examine some of these decisions in an attempt to show that history shows us that section 332(7) does not belong to the era we are in and if it was to be constitutionally challenged it is unlikely that it would survive. Emphasis will be put on the fact that we should not wait for a court challenge, but rather, the legislature should make a move towards the reform of corporate criminal liability and in so doing, eliminate reverse onus provisions that infringe upon the presumption of innocence.

Keywords: Corporate criminal liability; criminal liability of members of associations; constitutional right to be presumed innocent; reverse onus; common law regulation of criminal liability of directors

\section{Introduction}

Certain provisions in South African statutes that existed before the Constitution conflict with constitutional provisions and this has resulted in constitutional challenges of such provisions. Langa $\mathrm{J}$ made it clear that the responsibility of making the necessary amendments to such provisions so as to ensure that they are in line with the Constitution lies with the legislature. ${ }^{1}$ This, however, does not always happen, hence the continued existence of some outdated provisions that are clearly in conflict with the Constitution. ${ }^{2}$ With specific regard to corporate criminal liability a provision that was not in line with the Constitution was challenged in $S v$ Coetzee and had to be resolved by the judiciary instead of the legislature. ${ }^{3}$ It is in that specific matter that

1 "Important provisions of old legislation, and in particular the (Criminal Procedure) Act, are being struck down because they are inconsistent with the Constitution, leaving gaps in the law which only the legislature can fill. It is primarily the task of the legislature, and not the courts to bring old legislation into line with the Constitution". See $S v$ Coetzee at 442I.

2 For instance, the Riotous Assemblies Act 17 of 1956 contains some provisions that will unlikely survive constitutional challenges. 
the statement above was made by Langa J. In that case the court had to determine, among other issues, whether the reverse onus provision that was contained in section 332(5) of the Criminal Procedure Act 51 of $1977^{4}$ was in line with the Constitution or not. This was thoroughly deliberated on and in the majority judgement it was made clear that the reverse onus provision as found in section 332(5) of the Criminal Procedure Act is unacceptable under the current South African Constitution. ${ }^{5}$ The judgement is a profound development in corporate criminal liability in South Africa. ${ }^{6}$

It is twenty years since Langa $\mathrm{J}$ delivered that important judgement on behalf of the majority. However, section 332 of the Criminal Procedure Act still contains a reverse onus provision that is valid and which operates in the same manner as the rejected reverse onus that was found in section 332(5). This reverse onus provision is contained in section 332(7) of the Criminal Procedure Act. The purpose of this article is to ascertain the continued validity of the reverse onus provision as contained in section 332(7) and to determine whether it is likely or unlikely to survive the test of constitutionality. Section 332(7) and its effects will now be discussed. This will be followed by a discussion of how section 332(5) was declared unconstitutional. In the following discussion it will be shown how loathe the Constitutional Court is towards reverse onus provisions. And, in conclusion, it will be made clear that the likelihood of the reverse onus provision in section 332(7) withstanding constitutional scrutiny is very little.

\section{Section 332(7) and the reverse onus provision}

Corporate criminal liability refers to the holding of a corporation criminally liable for crimes it has committed or for crimes that have been committed in endeavouring to pursue the interests of the corporation. ${ }^{7}$ In the same way that crimes can be committed by corporations, they may also be committed in furthering or endeavouring to further interests of associations that do not have juristic personality. In such circumstances corporate criminal liability is also relevant and applicable. Unfortunately, corporate

$3 \quad$ Sv Coetzee at 379.

4 According to sec 332(5) "(w)here an offence has been committed, whether by the performance of any act or by the failure to perform any act, for which any corporate body is or was liable to prosecution, any person who was, at the time of the commission of the offence, a director or servant of the corporate body, shall be deemed to be guilty of the said offence, unless it is proved that he did not take part in the commission of the offence, and that he could not have prevented it, and shall be liable to prosecution therefor, either jointly with the corporation or apart therefrom, and shall on conviction be personally liable to punishment therefor".

5 For a discussion of some of the judgements in the case see Schwikkard 1999: 148-150 and Farisani 2010: 254-258.

$6 \quad$ Idem at 251-264.

7 For an overview of corporate criminal liability in South Africa see Burchell 2013: 448-460; Kunst, Delport \& Vorster 2011: Appx 5-14; and Farisani 2012: 252-265. 
criminal liability is one of the areas of South African law which has experienced very little development, in spite of the drastic increase of corporations that has been accompanied by an increase in corporate criminality between the time the 1977 Act became operational and now. An example of the lack of development is that while there are jurisdictions that have developed to the extent that they have separate statutes for specific crimes that may be committed by corporations, ${ }^{8}$ in South Africa the provision refers to crime generally, ${ }^{9}$ regardless of the type of crime that has been committed. There has been an outcry over the lack of development in corporate criminal liability and commentators have called for the reform of that area of South African law. ${ }^{10}$

Section 332(7) of the Criminal Procedure Act allows for the criminal liability of members of associations, such as partnerships, ${ }^{11}$ that lack juristic personality. The inclusion of the criminal liability of members of associations in the provision dealing with corporate criminal liability has been done since the first statutory provision regulating corporate criminal liability in South Africa, namely section 384 of the Criminal Procedure and Evidence Act. ${ }^{12}$ It shows the acceptance of the principle that whether an entity is incorporated or not when crimes have been committed, criminal liability should be imposed. Section 384 of the Criminal Procedure and Evidence Act was subsequently amended by section 117 of the Companies Amendment Act, ${ }^{13}$ and its heading was "The prosecution of corporations and members of associations".

This section is the one that clearly pointed out the inclusion of unincorporated entities. Section 381 of the Criminal Procedure Act, $1955^{14}$ replaced the previous provision and it retained the heading "Prosecution of corporations and members of associations". This section was repealed and replaced by the current statutory regulation, section 332, which has retained the same heading but fails to give adequate attention to the criminal liability of members and managers of those entities that do not have legal personality. Only sub-sections seven, eight and nine focus specifically on the liability of members of associations and they do so very briefly. The current position in section 332 is lacking when compared with the position in other foreign jurisdictions such as the United Kingdom ${ }^{15}$ where the relevant statute gives adequate focus to both incorporated and unincorporated entities.

8 For instance the United Kingdom's Corporate Manslaughter and Corporate Homicide Act 2007.

9 Section 332(1) states that a corporation may be held liable for "any offence".

10 Nana 2011: 81-104; Borg-Jorgensen \& Van der Linde (part 1) 2011: 452-465; Borg-Jorgensen \& Van der Linde (part 2) 2011: 684-702; Farisani 2009: 210-226.

11 It was confirmed that partnerships form part of associations that fall under the ambit of sec 384 of the Criminal Procedure and Evidence Act 31 of 1917 (now sec 332) in $R v$ Levy at 320-321.

12 Section 384 of the Criminal Procedure and Evidence Act 31 of 1917.

13 Companies Amendment Act 23 of 1939.

14 Criminal Procedure Act 56 of 1955.

15 The Corporate Manslaughter and Corporate Homicide Act specifies that a partnership, trade union or employers' association fall under the ambit of the Act and detailed attention is given to the prosecution of those entities. 
The wording of section 332(7) is exactly the same as the wording used in the invalidated section 332(5). ${ }^{16}$ It provides that any person who was a member of an association of persons ${ }^{17}$ when a crime was committed by the "association", will be convicted of that crime unless such person discharges the onus of proving that he or she did not take part in the commission of the offence and that he or she could not have prevented it. The effect of section 332(7) is that the accused's right to be presumed innocent is infringed upon ${ }^{18}$ and as Schwikkard and Van der Merwe ${ }^{19}$ point out, "[t]he presumption of innocence both at common law and as a constitutional right places a burden on the prosecution to prove the guilt of an accused person beyond reasonable doubt". Firstly, section 332(7) places the burden on the defence and not on the prosecution. Secondly, as the burden to disprove guilt is on a balance of probabilities, it is possible for the accused to be convicted in spite of the presence of reasonable doubt. ${ }^{20}$ Section 332(5) had the same effect.

The difference between section 332(5) and section 332(7) is that the former deals with the criminal liability of individuals (servants and directors) in corporations (entities with juristic personalities) while the latter refers to individuals (members) in associations that do not have juristic personality. A reading of section 332(5) and of section 332(7) shows that both sections make provision for a reverse onus in the same way. As with section 332(5) the criticism against section $332(7)^{21}$ is that the reverse onus provision that is found in the sub-section is a direct infringement of the presumption of innocence which is constitutionally entrenched. ${ }^{22}$

Both provisions were also found to be making use of the same test to determine liability. The court in $S v$ Klopper $^{23}$ found that in terms of sub-section five and seven

16 For the wording of sec 332(5) see n 4 supra. Section 332(7) states that "[w] hen a member of an association of persons, other than a corporate body, has, in carrying on the business affairs of that association or in furthering or endeavouring to further its interests, committed an offence, whether by the performance of any act, any person who was, at the time of the commission of the offence, a member of that association, shall be deemed to be guilty of the said offence, unless it is proved that he did not take part in the commission of the offence and that he could not have prevented it: provided that if the business or affairs of the association are governed or controlled by a committee or other similar governing body, the provisions of this sub-section shall not apply to any person who was not at the time of the commission of the offence a member of that committee or other body".

17 In this context the term "association of persons" refers to an entity that lacks juristic personality.

18 Section 332(7) creates a mandatory presumption. Mandatory presumptions make it possible to have a "conviction in the absence of proof beyond a reasonable doubt". See Morton \& Hutchison 1987: 109.

19 2009: 514.

20 "There is clear authority for the view that the presumption of innocence will be infringed whenever there is a possibility of a conviction despite the existence of a reasonable doubt": Schwikkard \& Van der Merwe 2009: 514.

21 "Whether these provisions of sec 332(7) are compatible with the Constitution, is very doubtful": see Snyman 2014: 248.

22 See sec 35(3)(h) of the Constitution of the Republic of South Africa 108 of 1996.

23 Sv Klopper 1975 (4) SA 773 (A) at 774. 
of the predecessor of section 332 of the Criminal Procedure Act, namely section 381 of the Criminal Procedure Act 1955, a subjective test is applied to determine liability. ${ }^{24}$ It is noteworthy that in spite of the similarities between section 332(5) and section 332(7), the latter remains valid while the former has been invalidated by the Constitutional Court. Over the years failure to discharge the reverse onus has led to the conviction of members of associations that do not have juristic personality. An example is $R v$ Kekane $^{25}$ in which a conviction was upheld as the appeal court confirmed the lower court's conclusion that the members of the association had failed to discharge the onus of proving that, firstly, they had not taken part in the offence and, secondly, that they could not have reasonably prevented the offence. ${ }^{26}$

In comparison to section 332(5) it is evident that in enacting section 332(7), the legislature was more lenient to a member of an association of persons than it was to a director of a corporation because, unlike section 332(5), section 332(7) contains a proviso that in the event that the governance of the association is through a committee or governing body, if that member did not belong to that committee or governing body at the time of the commission of the crime, he or she would escape liability. Section 332(5) did not contain such a proviso. It may be that the rationale behind such a proviso is that it is the governing body that is the actual decision-making body of the association and if one belongs to that body, one should not be allowed to escape liability; however, where one does not belong to that body it makes sense to give such a person the benefit of the doubt. Moreover, it can be argued that where a person who is a member of a governing body claims that he or she is unaware of the fact that a crime was being committed, such a person is justifiably punished for his/ her negligence.

The existence of this proviso is important as it raises the question as to whether it has anything to do with the continued validity of section 332(7) or rather, the reluctance to challenge the constitutionality of section 332(7). It is indeed a possibility that it is the proviso in section 332(7) that has kept the section from being constitutionally challenged, however this may be fallacious reasoning. Kunst, Delport \& $\operatorname{Vorster}^{27}$ correctly points out that the proviso

contains only exempting provisions, i.e. it exempts from the deeming (main) provisions of the sub-section, if the business or affairs of the association are governed or controlled by a committee or other similar governing body, any member of the association who was not a member of such committee or other body at the time of the commission of the offence.

24 "Sub-section 5 (and also sub-sec 7) of sec 381 does not lend support to an argument that only an objective interpretation would give meaning to the second proviso - even a subjective interpretation establishes criminal liability which did not exist under the common law": see $S v$ Klopper at 774.

$25378 \& 384$.

26 Ibid. 
It is submitted that the existence of an exemption in section 332(7) does not provide justification for the continued existence or validity of this sub-section.

In $S v$ Ismail, ${ }^{28}$ one of the cases in which sub-section 7 was dealt with, instead of a governing body there was a "regional command" which the court did not regard as a committee or governing body as it turned out to be a self-appointed body which existed although some of the members objected to it. ${ }^{29}$ This begs the question whether in the absence of a formally recognised governing or controlling body the effect of section 332(7) is not harsher than that of the invalidated section 332(5) since where the proviso is not applicable it is the ordinary members of the associations who will be subjected to the effects of section 332(7). Whereas section 332(5) refers to servants and directors, history has shown that it has mainly affected servants in decision-making positions as well as those individuals who had been given the mandate to lead the corporations as directors. ${ }^{30}$ The same cannot be said about ordinary members of associations lacking criminal liability. Section 332(7) makes it clear that when there is no formal governing or controlling arrangement, those who are presumed guilty are the members of such associations. Kruger ${ }^{31}$ correctly submits that "if there is no elected management, the members severally will, in fact, be liable". This refers to ordinary members of such associations, including those who may not be involved in decision-making processes. It is submitted that this is a serious violation of the right of such ordinary members of associations to be presumed innocent as they are presumed guilty in spite of their lack of involvement and possibly even inability to be involved in the commission of the crime due to the minimal role they may be playing in the association. The violation of this right is caused by section 332(7) which appears to have far-reaching consequences when compared to section 332(5). In addition Kruger" ${ }^{32}$ observes that "the objections to sub-section five apply to an even greater extent to sub-section seven and the latter will probably not survive constitutional scrutiny".

Although the legislature has not acted in accordance with Langa J's suggestion that it should take responsibility for ensuring that old provisions are in line with the Constitution, it is rather strange that, to date, the provision has not been constitutionally challenged. Apart from Kruger, several commentators have pointed out that if it were to be constitutionally challenged, section 332(7) would not withstand such a

$28 \quad 1965(1)$ SA $452(\mathrm{~N})$ at 459.

29 "The regional command was in no way representative of the members, nor were they leaders which the members had appointed or approved or in some cases even knew of. I take the view, then, that sec 381(7) does not apply": Sv Ismail at 459.

30 In line with the system followed in South Africa there are certain people within the corporation whose actions are imputed to the corporation in order for the corporation to be held liable and these are usually directors and employees in senior positions.

31 2008: 33-38.

32 Idem at 33-37. 
challenge.$^{33}$ Snyman,${ }^{34}$ for example, avers that the decision in $S v$ Coetzee creates doubt as to whether the provisions of section 332(7) are in line with the Constitution.

Section 332(7) also allows for the criminal liability of members of associations that were formed for unlawful purposes. ${ }^{35}$ This was held by Milne J in $S v$ Ismail and it is a decision agreeing with the company law principle of piercing the corporate veil. If this was not the case, individuals would form such associations and freely act unlawfully in the name of the association. According to Milne $\mathrm{J}$ where an accused chooses to become a member of an association which has been formed in order to act unlawfully, such a member has no one to blame but himself or herself. ${ }^{36}$

It must be noted that in $R v$ Limbada, which was based on the same provision in section 381 of the Criminal Procedure Act, 1955, a suspended sentence was meted out to one of the appellants on the basis that "her guilt arises from the provisions of section 381(7) and is presumptive rather than positively established". ${ }^{37}$ The question that arises is whether this reverse onus provision has room to exist in our Constitutional sphere.

\section{The reverse onus provision in section 332(5) and $S v$ Coetzee}

As already stated above, $S v$ Coetzee was a Constitutional Court case that dealt with, among others, whether section 332(5) of the Criminal Procedure Act, 1977 was constitutional or not. In this particular case the challenge in the Constitutional Court was based on the aversion that it infringed upon the constitutional right to be presumed innocent as provided by the then section 25(3)(c) of the Interim Constitution. ${ }^{38}$ The matter was brought to court by persons who were being charged with, inter alia, fraud in the Witwatersrand Local Division. A request was made by these persons to challenge the constitutionality of two sections of the Criminal Procedure Act and the trial was consequently suspended to allow for the challenge of those provisions, one of which was section 332(5). ${ }^{39}$ As stated above, section

33 Snyman 2014: 248; Burchell 2013: 458; Farisani 2012: 263; Kemp 2015: 244.

34 2014: 248.

35 "It would be anomalous, indeed, if it were held that members of a lawful association could be made liable under this sub-section in the absence of proof of non-participation and inability to prevent the crime though committed by another and that members of an association formed for unlawful purposes should be better off. The fact that the burden of showing that he could not have prevented the crime would be virtually impossible to discharge is not a sufficient reason for holding that the sub-section does not apply to unlawful organizations": $S v$ Ismail at 459.

36 Sv Ismail at 458 .

$37 \quad R v$ Limbada at 490.

$38 S v$ Coetzee at 447D-E. This refers to sec 25(3)(c) of the Constitution of South Africa Act 200 of 1993. A more detailed discussion of this case may be found in Farisani 2016: 141-149.

$39 S v$ Coetzee at 443B. 
332(5) provided a reverse onus provision which required the accused to disprove his or her guilt. This contradicts the presumption of innocence and moves the onus from the prosecution (the state) to the defence, resulting in a state of affairs that is in contravention of the Constitution.

In essence, with regard to section 332(5), the Constitutional Court had to determine whether the constitutionally-entrenched and fundamental right of an accused person to be presumed innocent until proven guilty was infringed by section 332(5) or was not infringed by section 332(5). Basically, section 332(5) made it possible for a presumption of guilt, as opposed to the presumption of innocence, to be made against a servant or director of the accused corporation. This means that where a corporation has been found guilty of having committed a crime, its director or servant is automatically presumed to be guilty of that crime. In order to avoid liability, that director or servant would be required to provide the court with proof, albeit on a balance of probabilities, that he or she did not take part in the offence and that he or she could not have done anything to prevent the crime from being committed. Section 332(5) therefore effectively made it possible for a director or a servant to be convicted without the prosecution having established guilt on the part of that director or servant.

It was argued that section 332(5) was a violation of the constitutionally guaranteed right to be presumed innocent and it made it possible for an accused to be convicted even though there could be reasonable doubt that the director or servant is actually guilty. ${ }^{40}$

After careful consideration, the Constitutional Court declared section 332(5) to be unconstitutional and therefore invalid. However, the decision was not unanimous. In passing judgment the judges made observations and relevant statements regarding section 332(5) as well as the Constitution. In delivering the majority judgment, Langa $\mathrm{J}$ stated that it is not the judiciary, but rather the legislature which ought to carry the responsibility of bringing old provisions, contravening the Constitution, in line with the Constitution. ${ }^{41} \mathrm{He}$ referred to the constant challenges, in court, of outdated provisions that have been carried over from the pre-Constitution regime. ${ }^{42}$ With regard to the Criminal Procedure Act he pointed out its relevance, but emphasised that it is legislation that came from "a different constitutional era in which the legal validity of its provisions could not be questioned" ${ }^{43}$ Prior to the coming into being of the Constitution where section 332(5) was at issue, the courts, even though they may have felt the need to challenge its validity, were bound to enforce the law as it was.

$40 S v$ Coetzee at $445 \mathrm{D}$.

41 See 1 supra. For summaries of Langa J's judgement on behalf of the majority, see Farisani 2010: 257 and Schwikkard 1999: 47-48, 114 \& 148.

$42 S v$ Coetzee at $442 \mathrm{G}$.

43 Ibid. 
Langa $J$ thereupon mentioned section 384(5) (the origin of section 332[5]) of the Criminal Procedure and Evidence Act. ${ }^{44} \mathrm{He}$ traced the development of the section from its original form to the current wording of section 332(5) and showed the minimal change in its form from that time until the coming into being of section 332(5) of the Criminal Procedure Act. Langa pointed out that the bone of contention, which has led to the constitutional challenge, is the "reverse onus" that section 332(5) placed on accused persons. ${ }^{45} \mathrm{An}$ argument brought before the court was to the effect that, in practice, the reverse onus in section 332(5) was a justifiable limitation, ${ }^{46}$ because in spite of the reverse onus, the onus of proving that the accused was aware of the commission of the crime was still borne by the prosecution. In making this contention cases such as Limbada and Klopper were relied on.

In response to this argument, Langa $J$ averred that section 332(5) did not place the onus of proof on the prosecution. ${ }^{47} \mathrm{He}$ looked at the "plain meaning" ${ }^{48}$ of section 332(5) and stated that section 332(5) simply provided for the conviction of an accused, who - at the time of the commission of the crime - was a director or servant of the company, as soon as the prosecution discharged the onus of proving that a crime was committed by a corporation. In terms of the plain meaning of section 332(5) such accused director or servant was obliged to prove that he or she did not take part in the offence and could not have done anything to prevent it, so as to escape conviction. Langa $J$ referred to the cases that the state had relied on $^{49}$ and showed that instead of providing support for their argument, ${ }^{50}$ those cases were actually in support of how he found the plain meaning to be. He clarifies what the relevant passages in those cases mean.

Regarding the constitutionality of the reverse onus provision, Langa J examined previous cases of the Constitutional Court and stated that the "Court has left open the question of the effect which a provision, which requires the accused to prove an exemption, exception or defence, has on the presumption of innocence". ${ }^{51}$ Since the applicants together with the Government relied heavily on Canadian decisions in their

$44 S v$ Coetzee at $446 \mathrm{G}$ and $447 \mathrm{~A}, \mathrm{~B} \& \mathrm{C}$.

45 "It was argued that the onus cast upon the accused relates to an essential element of the offence created by the section and that the reversal of the onus meant that the accused could be convicted despite the existence of a reasonable doubt with regard to his or her guilt. This reverse onus was therefore said to violate the right to be presumed innocent as enshrined in $\sec 25(3)$ (c) of the Constitution as well as the "cluster of rights associated with it"': $S v$ Coetzee at 447D \& E.

$46 S v$ Coetzee at 448A.

$47 \quad S v$ Coetzee at 448B.

48 "[T]he plain meaning of the words is that once the prosecution proves that an offence has been committed by a corporate body of which the accused was a director or servant at the time of commission, the latter can escape conviction only by proving that he or she did not take part in and could also not have prevented the commission of the offence": see $S v$ Coetzee at 448B \& C.

$49 \mathrm{R} v$ Limbada at 481; $S$ v Klopper at 773.

$50 S v$ Coetzee at 449B.

51 Idem at $451 \mathrm{~A} \& \mathrm{~B}$. 
arguments, Langa J examined the Canadian courts' handling of the constitutionality of a reverse onus. He mentioned that in terms of the Canadian Charter of Rights and Freedoms there was a presumption of innocence until the accused person was proven guilty. ${ }^{52}$ In examining the specific cases that were relied on, he pointed out that in those cases the accused were not at risk of being found guilty while there was reasonable doubt regarding their guilt. ${ }^{53}$

He concluded that section 332(5) is an infringement of the constitutional right to be presumed innocent and - among other things - averred that "the objection which is fundamental to the reversal of onus in this case is that the provision offends against the principle of a fair trial which requires that the prosecution establish its case without assistance from the accused" ${ }^{54}$ Langa $\mathrm{J}$ further stated that section 332(5) was not aimed at creating liability without fault on the part of the accused. ${ }^{55}$ Its aim was to ensure the conviction of directors who took part in the commission of crimes or who were in a position to prevent the commission of a crime, but failed to do so. ${ }^{56}$ Fault was therefore an important element of section 332(5) and it was an element that had to be proven. ${ }^{57}$

On whether the infringement of the presumption of innocence by section 332(5) was a justifiable limitation in terms of section 33(1) of the Interim Constitution, Langa $J$ recognised the importance of protecting society and corporations from directors who failed to prevent the commission of crimes. He stated that it is possible to achieve that without resorting to the reverse onus and proposed alternative means that could be relied on to fulfil the intention of section 332(5). ${ }^{58}$ This was reiterated by Mokgoro J who stated that even though she is concerned about what

52 Section 11(d) of the Canadian Charter of Rights and Freedoms of 1982 states as follows: "11. Any person charged with an offence has the right ... (d) to be presumed innocent until proven guilty according to law in a fair and public hearing by an independent and impartial tribunal": $\operatorname{see} S v$ Coetzee at $451 \mathrm{G}$.

53 Langa $\mathrm{J}$ showed that the provisions in the Canadian cases that the State had relied on to support the validity of the reverse onus "did not impose a reverse onus and that there was no danger that the accused could be convicted despite the existence of a reasonable doubt": $S v$ Coetzee at 454A. See, also, Farisani 2016: 144-146 for a more detailed discussion.

$54 \quad S v$ Coetzee at $454 \mathrm{~F} \& \mathrm{G}$.

55 Idem at $456 \mathrm{C}$.

56 Idem at $456 \mathrm{C} \& \mathrm{D}$.

57 Langa goes on to state that "what causes the provision to fall foul of the presumption of innocence here is the effect of merely changing the form of the provision to require the accused, rather than the prosecution, to prove elements which are essential to his or her guilt or innocence. There is manifest unfairness where the legislature, having created an offence potentially entailing very grave penalties, goes on to subvert an important constitutionally protected right by requiring crucial elements of the offence to be proved or disproved by the accused on pain of conviction should the onus not be discharged": $S$ v Coetzee (n 1) 456G \& H.

58 "I can see no reason, however, why the State could not, for example, impose appropriate statutory duties on directors and other persons associated with the corporate body, aimed at ensuring that its affairs are honestly conducted and that it is itself protected against dishonest conduct. This could be done in a variety of ways by means of appropriate legislative provisions which might, for instance, impose the duties of disclosure and reporting on the corporate body, its directors, servants and other persons involved with its affairs. There has been no suggestion that such measures, 
she termed "the dangers of corporate activity",, 59 the infringement of the presumption of innocence remains unjustifiable. The majority judgment was that section 332(5) was unconstitutional. ${ }^{60}$

Although recommendations of saving the provision through the severing of words or phrases that made it unconstitutional were made, these were not supported by the majority. In her judgement, O'Regan J recommended saving section 332(5) through severing the bad parts, such as the word "servant" and the phrase "it is proved that he did not take part in the commission of the offence", ${ }^{61}$ while maintaining the parts of section 332(5) that are good. ${ }^{62}$ Mokgoro J agreed with O'Regan J with regard to saving the provision by means of severance. ${ }^{63}$

Madala $\mathrm{J}$, in his minority judgment, did not find section 332(5) to be unconstitutional. ${ }^{64}$ Although he recognised the importance of the presumption of innocence he averred that it is not an absolute right. ${ }^{65}$ In contrast, Sachs J concurred with the majority, however he gave a separate judgment in which he addressed several issues, including the history and rationale of section 332(5). He explained the fact that there was a view that a fine as a sanction for corporations that committed crimes was an inadequate way of addressing such crimes. ${ }^{66} \mathrm{He}$ emphasised the need to punish the individuals within the company, as companies committed crimes through such individuals. ${ }^{67}$

enforced through appropriate sanctions, could not accomplish as effectively the ends sought to be achieved by sec 332(5) of the Act. It has further not been contended that such objectives could not be achieved without placing an onus on the accused to prove any aspect of his or her innocence in a criminal prosecution for a breach of such duty. I am accordingly not persuaded that the reverse onus provisions in sec 332(5) are necessary ..." ": $S v$ Coetzee at 457H-458A.

$59 S v$ Coetzee at 497A.

60 Langa J, Chaskalson P, Mahomed DP, Kriegler J, Sachs J, Ackermann J \& Didcott J.

$61 S v$ Coetzee at 516.

62 Ibid.

63 "As regards the order in this case, I concur with O'Regan J that severance of certain words from sec 332(5), so that the legal burden of proof is removed from the accused, is an appropriate remedy in this case": $S v$ Coetzee at 497C. Also see discussion in Schwikkard 1999: 159-162.

64 He states that "the mere fact that a section provides that an accused person may be convicted in circumstances in which there is a reasonable doubt is not in itself a sufficient reason for regarding such sections as unconstitutional. There may be circumstances in which the reverse onus provision is necessary and justifiable": see $S v$ Coetzee at $491 \mathrm{H}$.

65 "I have no doubt in my mind that the presumption of innocence is a fundamental right which plays a pivotal role in our criminal justice system. However, in my view, like all other rights and freedoms guaranteed by the Constitution, this right is not absolute, but that its value and weight will differ according to a variety of factors and circumstances against which it is pitted on the scales": see $S v$ Coetzee at $493 \mathrm{H}-\mathrm{I}$.

$66 \quad S v$ Coetzee at 516D-F.

67 Sachs notes that "as the eyes, ears and spokesperson of the corporation ... it would not be unreasonable to hold them personally to account for the misdeeds of those obliged to do their bidding, provided that this was done by penalizing them for culpable lack of concern for keeping the company on the straight and narrow, rather than by attributing equal guilt when such could not be proven in the ordinary way": see $S v$ Coetzee at 518A-B. 
The judgments in Coetzee provide an explanation of the intended objective of section 332(5) and they emphasise the harshness of its operation, notably on innocent directors who fail to provide the required proof. The judges took into account foreign law and also considered how the Constitutional Court had handled the presumption of innocence on previous occasions. The matter was not lightly taken and various factors in balancing the competing rights were taken into account.

As a result of the judgement, the common law position currently applies, namely that corporations are criminally liable for crimes committed by their servants and/or directors and such servants or directors may be held liable for offences committed by the corporation if a specific servant or director satisfies the requirements for the common law offence of being an accomplice, ${ }^{68}$ namely "only if he took part in that other's crime, or on the basis of vicarious liability or agency". ${ }^{69}$

Where the director is held liable on the basis of being an accomplice the elements that must be proven are unlawful conduct and mens rea (culpability). ${ }^{70}$ It must be noted, however, that "apart from his own act and culpability there must have been an unlawful act committed by someone else which corresponded with the definitional elements of the relevant crime and was accompanied by the required culpability". ${ }^{71}$ It must be proven that the director "furthered or assisted" in the commission of a crime. ${ }^{72}$ Burchell ${ }^{73}$ points out that furthering or assisting in the commission of a crime can occur in various ways, including, commanding the commission of the crime and encouraging the commission of a crime.

The liability of a director based on vicarious liability in terms of the common law "concerns the liability of an accused who has not personally committed the prohibited act in question" 74 and the elements that must be proven are unlawful conduct and fault ${ }^{75}$ on the part of the accused director. ${ }^{76}$ Although it is pointed out

68 "The judgment was given on 6 March 1997 but no amendment has been forthcoming. Presumably the government accepts that the liability of directors and employees for offences of their companies is determined in accordance with the common law principles of vicarious liability": see Kruger 2008: 33-37; and: "In my view there would be a duty on the director to act to prevent the commission of acts which would render the company to criminal prosecution and his intentional failure to prevent the commission of these acts, if he were in a position to do so, would render him criminally liable as a socius criminis": Ackermann J in S v Coetzee at 464B. See, also, Burchell 2013: 478-479.

69 Idem at 567. See, further, Kemp 2015: 244: "Therefore as matters stand at present, it is only the corporate entity that can be held liable for crimes committed by its directors or employees. The directors and employees cannot be held liable unless they actively associated themselves with the commission of the crime."

70 Burchell 2013: 496. See, also, Kemp 2015: 274-275.

71 Snyman 2014: 267.

72 Ibid.

73 2013: 496.

74 Kemp 2015: 238.

75 Burchell 2013: 442.

76 "As far as common law crimes are concerned, one can never be liable for a crime committed by another to which one was not a party and in respect of which one had no culpability. Vicarious liability is possible only in statutory crimes": Snyman 2014: 242. 
that when it comes to vicarious liability there is uncertainty as to whether fault is a pre-requisite or not, ${ }^{77}$ corporate criminal liability in terms of section 332 will only be applicable if there is the presence of fault / mens rea on the part of a director or servant that can be imputed to the corporation. ${ }^{78}$

Even though section 332(5) is being substituted by the common law while we wait for the legislature to reform the law, the criminal liability of a director for actions of the corporation committed by fellow directors or for having "actively associated themselves with the commission of the crime" ${ }^{\prime 79}$ should not be confused with the fact that generally South Africa's approach to corporate criminal liability is the derivative approach, which entails the imputation of the guilt of the director to the corporation. As Burchel1 ${ }^{80}$ confirms: "[T] he criminal liability of a corporate body in South Africa went wider than that of the vicarious liability of natural persons; and it rested upon the imputation to the corporation of the crimes of persons acting on their behalf, rather than upon vicarious liability."

\section{The Constitutional Court's antipathy towards the reverse onus}

As seen from the discussion above, $S v$ Coetzee serves as an illustration of the fact that the Constitutional Court is loathe to allow for reverse onus provisions to continue to exist in South African law. Apart from $S v$ Coetzee, there are a number of Constitutional Court cases that demonstrate the Constitutional Court's strong aversion against reverse onus provisions. These cases will be discussed below, as a way of showing that should section 332(7) be challenged, the Constitutional Court is likely to invalidate it, as it has done with other similar provisions. The cases referred to below were heard just before or around the same time as $S v$ Coetzee. Logically, the Constitution had just come into effect and it was mainly during that time that provisions that appeared to infringe the Constitution were challenged in the then newly established Constitutional Court.

In the 1995 case of $S v Z u m a,{ }^{81}$ which was heard prior to $S v$ Coetzee, the section in question was section 217(b)(ii) of the Criminal Procedure Act which created a reverse onus. The court found the section to be invalid and in passing judgement ${ }^{82}$ Kentridge JA pointed out that the reverse onus in that section "seriously compromised

811995 (4) BCLR 401 (CC) at par 46.

82 "Accordingly sec 217(b)(ii) does not meet the criteria laid down in sec 33(1) of the Constitution. It is inconsistent with the Constitution and in terms of sec 98(5) of the Constitution it must be declared invalid": $S$ v Zuma (n 81) par 39. 
and undermined" ${ }^{\prime 3}$ the rights in question. Those compromised and undermined rights are "the right to remain silent after arrest, the right not to be compelled to make a confession and the right not to be a compellable witness against oneself" ${ }^{84}$

Also, prior to $S v$ Coetzee, the Constitutional Court in $S v$ Bhulwana; $S v$ Gwadiso $^{85}$ declared that section 21(1)(a)(i) of the Drugs and Drug Trafficking Act ${ }^{86}$ was unconstitutional and therefore invalid, due to its reverse onus provision. In finding that the reverse onus provision was not consistent with the Constitution, O'Regan $J$ referred to the risk of a conviction in spite of reasonable doubt as to the guilt of the accused. ${ }^{87}$ Such a risk should be avoided as it negates the basic duty of the prosecution to provide proof of guilt beyond reasonable doubt before a conviction can be made in a criminal case. Also in 1996 section 40(1) of the Arms and Ammunition $\mathrm{Act}^{88}$ was challenged in $S v$ Mbatha; $S v$ Prinsloo $^{89}$ for creating a reverse onus through its presumption of possession. The presumption arose simply due to the fact that the item in question had at some point been on the premises. As with section 332(5) in Sv Coetzee, Langa J declared that the provision infringed upon the presumption of innocence. He further stated that "it would be undesirable for the courts to continue applying a provision which is not only manifestly unconstitutional, but which also results in grave consequences for potentially innocent persons in view of the serious penalties prescribed". ${ }^{90}$ This statement by Langa $J$ is a clear indication that the Constitutional Court does not take kindly to provisions such as section 332(7) that allow for a reverse onus and by so doing, infringe upon the right to be presumed innocent until proven guilty.

Another case, also heard in 1996, is $S \vee$ Julies,${ }^{91}$ in which section 21(1)(a) (iii) of the Drugs and Drug Trafficking Act was successfully challenged and declared invalid ${ }^{92}$ by the Constitutional Court. According to that section there was a presumption of dealing if there is proof that the accused had been in possession of "undesirable dependence-producing substance other than dagga". ${ }^{93}$ This effectively was a reverse onus provision which the Constitutional Court correctly found to be inconsistent with the Constitution. $S$ v Bhulwana $S v$ Gwadiso $^{94}$ was cited in the decision in $S v$ Julies.

911996 (7) BCLR 899 (CC).

92 Idem at par 5.

93 Idem at 899.

94 See (n 89) par 34. 
In $S v$ Mello, ${ }^{95}$ also involving the Drugs and Drug Trafficking Act, ${ }^{96}$ section 20 of the Act, which contained a presumption of guilt, ${ }^{97}$ was challenged successfully in the Constitutional Court. In passing judgement, Mokgoro J cited $S v$ Mbatha; $S$ $v$ Prinsloo ${ }^{98}$ and made the important observation that "similar to the presumption embodied in section 40(1) of the Arms and Ammunition Act, the effect of the presumption in section 20 of the Act is that it shifts the onus to the accused to prove his or her innocence". ${ }^{99}$ Section 20 was therefore declared invalid. In Van Nell $v S^{100}$ a challenge was also brought against section 20 of the Drugs and Drug Trafficking Act, but it was referred back to the court $a$ quo to make a ruling in accordance with the decision in $S v$ Mello. ${ }^{101}$

The cases above provide a few examples of cases in which the Constitutional Court has declared that a provision containing a reverse onus provision that infringes upon the accused's right to be presumed innocent is inconsistent with the South African Constitution and, for that reason, invalid. It must be noted that there may be circumstances where a reverse onus is justifiable. ${ }^{102}$ However, the Constitutional Court is clearly against the notion of the infringement of the right to be presumed innocent, ${ }^{103}$ and section 332(7) "creates a reverse onus which violates the presumption of innocence and this presumption may not be justifiable in terms of the limitation clause". ${ }^{104}$ It is therefore highly unlikely that section 332(7) of the Criminal Procedure Act, which does infringe the accused's right to be presumed innocent, will survive a constitutional challenge. ${ }^{105}$

951998 (7) BCLR 908 (CC).

96 See (n 86) sec 20.

97 Presumption relating to possession of drugs: "If in the prosecution of any person for an offence under this Act it is proved that any drug was found in the immediate vicinity of the accused, it shall be presumed, until the contrary is proved, that the accused was found in possession of such drug": sec 20 Drugs and Drug Trafficking Act (n 86).

98 See (n 90) par 341.

$99 S v$ Mello at par 5.

1001998 (8) BCLR 943 (CC) at par 2.

$101 S v$ Mello had been decided by the Constitutional Court earlier that day and Mokgoro J (with the other judges concurring) referred the matter in Van Nell $v S$ back to the court a quo to decide in accordance with the ruling in $S v$ Mello in which sec 20 was declared invalid, namely Van Nell $v$ $S$ at par 2 .

102 Schwikkard \& Van Der Merwe 2014: 517 note that "(a)lthough the Constitutional Court has made it clear that there may well be instances where a reverse onus provision is justified, it has been remarkably consistent in refusing to find justification for an infringement of the presumption of innocence".

103 Ibid.

104 Snyman 2013: 248.

105 This view is supported by several commentators as seen above, including Kemp who states that even though the section has not yet been constitutionally challenged "it would no doubt be found unconstitutional too for the same reasons as in Sv Coetzee": see Kemp 2015: 244. 


\section{Conclusion}

It is important to note that section 332(5) had been inherited from a pre-Constitution era when the legislature made laws and such laws could not be freely challenged. The time and the context of the promulgation of the Criminal Procedure Act are important as it was prior to the existence of the Constitution in South Africa; hence the existence of elements that are typical of a pre-Constitution piece of legislation. In $S v$ Coetzee the reverse onus presumption was successfully challenged in the Constitutional Court and as explained above, Langa $\mathbf{J}$ made it clear in that case that the duty to bring old provisions in line with the Constitution is the duty of the legislature. This has, however, not happened. As a result well in the twenty first century we still have section 332(7), a reverse onus provision, in section 332 of the Criminal Procedure Act. This begs the question whether such a provision should continue to form part of our law under the current constitutional dispensation.

The implications as well as the effect of section 332(5) and its predecessors operated in such a way that innocent directors, who were not aware that their colleagues were committing offences, were held criminally liable despite their innocence, if they were unable to disprove the presumption of guilt against them. The examples of $S v$ Coetzee and of the other cases in which the Constitutional Court declared reverse onus provisions invalid, are a clear indication that a provision that allows for a reverse onus, may lead to conviction in spite of a reasonable doubt regarding the guilt of the accused and this is highly undesirable in a constitutional state.

Section 332(7) shifts the onus from the prosecution to the accused, thus making it possible for the accused to be found guilty even if there is reasonable doubt, while in South African law all accused persons are presumed innocent until proven guilty. This is a violation of the accused's right to be presumed innocent as it allows for the accused to be found guilty without proof of guilt beyond reasonable doubt. Moreover, as illustrated above the effects of section 332(7) may in certain circumstances be even more severe than those of section 332(5). This is an unsatisfactory state of affairs and history shows us, as seen from the Constitutional Court's approach to reverse onus provisions that infringe upon the presumption of innocence, that section 332(7) does not have a place in this era and it is unlikely to survive a constitutional challenge.

The time has come to reform the law pertaining to corporate criminal liability instead of waiting for the constitutionality of section 332(7) to be challenged in court. When that is done, it must be ensured that provisions such a section 332(7) that allow for a reverse onus as well as provisions that may have the effect of allowing for a conviction even though there is a reasonable doubt as to the guilt of the accused are not included.

The principle in section 332(7) of ensuring that members of associations that do not have legal personality are held criminally liable for crimes committed in 
the furtherance of the interests of such associations is commendable; however, in reforming corporate criminal liability in South Africa, it would be advisable to have separate statutory provisions that deal with specific crimes that may be committed by incorporated and unincorporated entities. Such statutory provisions must, however, be all-inclusive with regard to the offenders and should refer to the criminal liability of corporations and directors thereof as well as to the criminal liability of members and managers of associations. Moreover, they must be worded in such a way that they do not contain reverse onus provisions that infringe upon the presumption of innocence.

\section{BIBLIOGRAPHY}

Borg-Jorgensen, Vicky-Louise \& Van der Linde, Kathleen (2011) "Corporate criminal liability in South Africa: Time for a change (part 1)" TSAR 3: 452-465

Borg-Jorgensen, Vicky-Louise \& Van der Linde, Kathleen (2011) "Corporate criminal liability in South Africa: Time for a change (part 2)” TSAR 4: 684-702

Burchell, Jonathan (2013) Principles of Criminal Law (Cape Town)

Farisani, Dorothy M (2009) "Corporate homicide: What can South Africa learn from recent developments in English law?" CILSA 42: 210-226

Farisani, Dorothy M (2010) " $S v$ Coetzee: Judge Albie Sachs and issues which "the Court is obliged to confront" SAPL 25(1): 251-264

Farisani, Dorothy M (2012) "Corporate criminal liability" in Esser, I \& Havenga M (eds) Corporate Governance Annual Review 2012 (Cape Town) 237-270

Farisani, Dorothy M (2016) “A comparative study of corporate criminal liability - Advancing an argument for the reform of corporate criminal liability in South Africa by introducing a new offence of corporate homicide" (unpublished thesis, University of KwaZulu-Natal)

Kemp, Gerhard (ed) (2015) Criminal Law in South Africa (Cape Town)

Kunst, Jennifer A, Delport, Piet \& Vorster, Quintus (2011) Henochsberg on the Companies Act 61 of 1973 (online version) (Durban)

Kruger, Albert (2008) Hiemstra's Criminal Procedure (Durban)

Morton, James C \& Hutchinson, Scott C (1987) The Presumption of Innocence (Toronto)

Nana, Constantine N (2011) "Corporate criminal liability in South Africa: The need to look beyond vicarious liability" J of African Law 55(1): 86-104.

Schwikkard, Pamela-Jane (1999) Presumption of Innocence (Kenwyn)

Schwikkard, Pamela-Jane \& Van Der Merwe, Steph E (2014) Principles of Evidence (Cape Town)

Snyman, CR (2014) Criminal Law (Durban)

\section{Legislation}

\section{Canada}

Canadian Charter of Rights and Freedoms of 1982 


\section{South Africa}

Arms and Ammunition Act 751969

Companies Amendment Act 23 of 1939

Constitution of South Africa Act 200 of 1993

Constitution of South Africa Act 108 of 1996

Criminal Procedure and Evidence Act 31 of 1917

Criminal Procedure Act 56 of 1955

Criminal Procedure Act 51 of 1977

Drugs and Drug Trafficking Act 140 of 1992

Riotous Assemblies Act 17 of 1956

\section{United Kingdom}

Corporate Manslaughter and Corporate Homicide Act 2007

\section{Case law}

$R v$ Kekane 1955 (4) SA 773 (A)

$R v$ Levy 1929 AD 312

$R v$ Limbada [1958] All SA 493

$S v$ Bhulwana; $S v$ Gwadiso [1996] 1 All SA 11 (CC)

Sv Coetzee 1997 SACR 379 CC

$S v$ Ismail (2) 1965 (1) SA 452 (N)

$S v$ Julies 1996 (7) BCLR 899 (CC)

Sv Klopper 1975 (4) SA 773 (A)

Sv Mbatha; Sv Prinsloo 1996 (3) BCLR 293 (CC)

$S v$ Mello 1998 (7) BCLR 908 (CC)

Sv Zuma 1995 (4) BCLR 401 (CC)

Van Nell v $S 1998$ (8) BCLR 943(CC) 